\title{
The "Nuts and Bolts" of Opioid Marketing: Promotional Messages to Family Doctors in Sacramento, Vancouver, Montreal, and Toulouse
}

\author{
Barbara Mintzes, $P h D^{7}$ (D) and Joel Lexchin, $\mathrm{MD}^{2}$

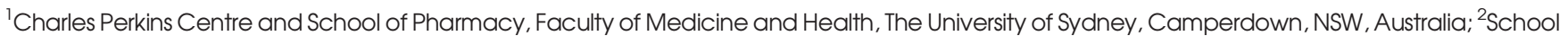 \\ of Health Policy and Management, Faculty of Health, York University, Toronto, Ontario, Canada.
}

$\mathrm{J}$ Gen Intern Med 35(12):3730-2

DOI: $10.1007 / \mathrm{s} 11606-019-05584-5$

(c) Society of General Internal Medicine 2020

$\mathrm{M}$ arketing activities by opioid manufacturers have been credited with fueling more frequent prescribing in primary care and promoting the expansion of use of their products to common chronic non-cancer pain conditions. ${ }^{1,2}$ In 2013-2015, the level of opioid-related mortality per US county was significantly associated with county-level per capita industry spending on physicians. ${ }^{3}$ Many of these payments originated in one-to-one visits from sales representatives, including meals and invitations to events. Limited information is publicly available on the information provided to doctors in these visits. Our team carried out a study of sales visits to primary care physicians in 2009-2010, at the height of opioid prescribing. ${ }^{4}$ We report here on physicians' perception of the main message in the subset of visits at which opioids were promoted along with physicians' perceptions of the quality of the information that they received and their prescribing intentions as a result of the visit.

\section{METHODS}

We recruited random samples of primary care physicians in Sacramento, Vancouver, Montreal, and Toulouse $(n=255)$ to report on consecutive sales visits. Physicians filled in a questionnaire per promoted drug on information provided on benefits and harms, the representative's key messages, and their impressions of information quality and accuracy. ${ }^{5}$ Data were collected from May 1, 2009, to June 30, 2010. Methods and results are described in detail elsewhere. ${ }^{5}$

This is a secondary analysis of reports on opioid promotions (ATC class NO2A) using duplicate independent coding (JL

Received November 6, 2019

Accepted November 25, 2019

Published online February 10, 2020 and $\mathrm{BM}$ ) of physicians' free text entries on sales representatives' key messages about the promoted drug (comments in French were translated into English). Key messages were then inductively independently classified into categories, with discussion of differences and resolution by consensus. SPSS version 22 was used to calculate descriptive statistics.

\section{RESULTS}

There were 69 opioid promotions by 16 companies, reported on by 54 physicians (1-4 per physician). The most commonly promoted drug was tramadol $(n=25$; $36 \%$ ), either alone or in combination with acetaminophen, followed by hydromorphone, codeine combination products, and morphine (Table 1).

Health benefits of opioids were discussed in $78 \%$ $(n=54)$ of promotion whereas in contrast, in over half of promotions $(n=37 ; 54 \%)$, no adverse events were mentioned (minor or serious). Serious adverse events were mentioned in $8(12 \%)$ promotions, including respiratory depression or arrest in 3 morphine promotions. Information on adverse effects sometimes aimed to reassure. For example, a doctor raised the risk of serotonin syndrome when tramadol is used in combination with SSRIs and reported that, "According to the sales representative, the drug label does not refer to this situation as dangerous and therefore the drug is not contraindicated." In contrast to the limited information on harms, safety claims, typically of a reassuring nature, were made nearly half the time $(n=34 ; 49 \%)$, e.g., well-tolerated, or a comparative claim, such as "better tolerated than narcotics" (tramadol).

The physicians also reported the sales reps' key messages, including, for example: "good drug if [you are] concerned about abuse, cannot get abused" (hydromorphone, Canada) and "[for] elderly patients not wanting any strong narcotics" (tramadol, United States). We classified these messages into 12 themes, listed in Table 2, with examples of claims per theme. The most frequent theme was effectiveness $(n=30)$. 
Table 1 Information Provided During One-to-One Sales Visits

\begin{tabular}{|c|c|c|c|c|c|c|c|c|c|c|c|}
\hline \multirow{2}{*}{$\begin{array}{l}\text { Promoted } \\
\text { opioid }\end{array}$} & \multirow{2}{*}{$\begin{array}{l}\text { Number of } \\
\text { promotions } \\
(n=69)\end{array}$} & \multirow{2}{*}{$\begin{array}{l}\text { US } \\
(n= \\
10)\end{array}$} & \multirow{2}{*}{$\begin{array}{l}\text { CA } \\
(n= \\
34)\end{array}$} & \multirow{2}{*}{$\begin{array}{l}\text { FR } \\
(n= \\
25)\end{array}$} & \multirow{2}{*}{$\begin{array}{l}\text { Companies } \\
\text { (promotions } \\
\text { per company) }\end{array}$} & \multicolumn{3}{|c|}{ Information provided } & \multirow{2}{*}{$\begin{array}{l}\text { Safety } \\
\text { claims } \\
(n=69)\end{array}$} & \multirow{2}{*}{$\begin{array}{l}\text { Samples } \dagger \\
(n=44)\end{array}$} & \multirow{2}{*}{$\begin{array}{l}\text { Food/ } \\
\text { drink } \dagger \\
(n=44)\end{array}$} \\
\hline & & & & & & $\mathbf{A E}$ & SAE & CI & & & \\
\hline Tramadol* & $25(36 \%)$ & 4 & 18 & 3 & $\begin{array}{l}\text { Janssen (7), } \\
\text { Labo-pharm } \\
\text { (7), Purdue (5), } \\
\text { Valeant (3), } \\
\text { Grunen-thal } \\
\text { (2), Meda (1) }\end{array}$ & $\begin{array}{l}10 \\
(40 \%)\end{array}$ & 0 & $\begin{array}{l}6 \\
(24 \%)\end{array}$ & $\begin{array}{l}12 \\
(48 \%)\end{array}$ & $17(77 \%)$ & $4(18 \%)$ \\
\hline Hydromorphone & $10(14 \%)$ & 0 & 10 & 0 & $\begin{array}{l}\text { Purdue (8), } \\
\text { Janssen (1), } \\
\text { Astellas (1) }\end{array}$ & $\begin{array}{l}2 \\
(20 \%)\end{array}$ & $\begin{array}{l}1 \\
(10 \%)\end{array}$ & $\begin{array}{l}2 \\
(20 \%)\end{array}$ & $\begin{array}{l}6 \\
(60 \%)\end{array}$ & $1(10 \%)$ & $1(10 \%)$ \\
\hline Codeine* & $7(10 \%)$ & & & 7 & $\begin{array}{l}\text { Bristol-Myers- } \\
\text { Squibb (4), } \\
\text { Pierre Fabre } \\
\text { (2), Mayolo } \\
\text { Spindler (1) }\end{array}$ & $\begin{array}{l}2 \\
(29 \%)\end{array}$ & 0 & $\begin{array}{l}1 \\
(14 \%)\end{array}$ & $\begin{array}{l}3 \\
(43 \%)\end{array}$ & 0 & 0 \\
\hline Morphine* & $7(10 \%)$ & 3 & 4 & 0 & $\begin{array}{l}\text { Abbott (4), } \\
\text { Pfizer (3) }\end{array}$ & $\begin{array}{l}3 \\
(43 \%)\end{array}$ & $\begin{array}{l}3 \\
(43 \%)\end{array}$ & $\begin{array}{l}1 \\
(14 \%)\end{array}$ & $\begin{array}{l}3 \\
(43 \%)\end{array}$ & 0 & $2(29 \%)$ \\
\hline Fentanyl & $6(9 \%)$ & 0 & 0 & 6 & $\begin{array}{l}\text { Janssen (3), } \\
\text { Cephalon (3) }\end{array}$ & $\begin{array}{l}5 \\
(83 \%)\end{array}$ & 0 & $\begin{array}{l}1 \\
(17 \%)\end{array}$ & $\begin{array}{l}5 \\
(83 \%)\end{array}$ & 0 & 0 \\
\hline Opium* & $6(9 \%)$ & 0 & 0 & 6 & Abbott (6) & $\begin{array}{l}5 \\
(83 \%)\end{array}$ & 0 & $\begin{array}{l}5 \\
(83 \%)\end{array}$ & $\begin{array}{l}4 \\
(67 \%)\end{array}$ & 0 & 0 \\
\hline Buprenorphine & $4(6 \%)$ & 0 & 1 & 3 & $\begin{array}{l}\text { Reckitt } \\
\text { Benckiser (3), } \\
\text { Purdue (1) }\end{array}$ & $\begin{array}{l}2 \\
(50 \%)\end{array}$ & $\begin{array}{l}2 \\
(50 \%)\end{array}$ & $\begin{array}{l}1 \\
(25 \%)\end{array}$ & $\begin{array}{l}1 \\
(25 \%)\end{array}$ & 0 & 0 \\
\hline Methadone & $1(1 \%)$ & 0 & 1 & 0 & Paladin & 1 & 1 & 1 & 0 & 0 & 0 \\
\hline Oxycodone & $1(1 \%)$ & 1 & 0 & 0 & Purdue & 0 & 0 & 0 & 0 & 0 & 0 \\
\hline Oxymorphone & $1(1 \%)$ & 1 & 0 & 0 & Endo & 1 & 0 & 1 & 0 & 0 & 0 \\
\hline Tapentadol & $1(1 \%)$ & 1 & 0 & 0 & Janssen & 1 & 0 & 0 & 0 & 0 & 1 \\
\hline Total & 69 & $\begin{array}{l}10 \\
(14 \%)\end{array}$ & $\begin{array}{l}34 \\
(49 \%)\end{array}$ & $\begin{array}{l}25 \\
(36 \%)\end{array}$ & & $\begin{array}{l}32 \\
(46 \%)\end{array}$ & $\begin{array}{l}8 \\
(12 \%)\end{array}$ & $\begin{array}{l}19 \\
(28 \%)\end{array}$ & $\begin{array}{l}34 \\
(49 \%)\end{array}$ & $18(41 \%)$ & $8(18 \%)$ \\
\hline
\end{tabular}

US United States (Sacramento); CA Canada (Vancouver and Montreal); FR France (Toulouse); AE adverse events (non-serious or serious); SAE serious adverse events; CI contra-indications

“*” includes combination products: tramadol/paracetamol $(n=9)$, codeine/paracetamol $(n=6)$, codeine/erysimum $(n=1)$ morphine/naltrexone $(n=$ 3), opium/paracetamol/caffeine $(n=6)$

†Percentages are of North American sales visits only; sales representatives in France are prohibited from providing samples and provision of food and drink (none provided)

Table 2 Themes of key messages reported in at least $5 \%$ of promotions ${ }^{\mathrm{a}}$

\begin{tabular}{|c|c|c|}
\hline Theme & $\begin{array}{l}\text { Frequency } \\
(n=65)^{b}\end{array}$ & Examples of sales representatives' key messages $^{c}$ \\
\hline Effectiveness & $30(46 \%)$ & $\begin{array}{l}\text { "better quality of life," oxycodone, US } \\
\text { "effective and safe," tramadol, Canada } \\
\text { "medicine that is adapted to pain." fentanyl, France }\end{array}$ \\
\hline Safety & $16(25 \%)$ & $\begin{array}{l}\text { "long acting safe medication for pain patients," tramadol, US } \\
\text { "without danger" fentanyl, France } \\
\text { "Tramacet is well-tolerated and safe." tramadol, Canada }\end{array}$ \\
\hline Convenience & $14(22 \%)$ & $\begin{array}{l}\text { "longer } 24 \text { hour effect," tramadol, Canada } \\
\text { "more flexibility compared with Actiq," fentanyl, France } \\
\text { "ease of dose adjustments," morphine, Canada }\end{array}$ \\
\hline Substitution & $8(12 \%)$ & $\begin{array}{l}\text { "of interest when stopping NSAIDs in patients with private insurance who require } \\
\text { treatment for chronic pain." tramadol, Canada } \\
\text { "Replace Diantalvic with Dafalgan + codeine," codeine/paracetamol, France }\end{array}$ \\
\hline Low addiction/abuse & $6(9 \%)$ & $\begin{array}{l}\text { "It has the unique property of being ineffective if tampered with, so it is less likely } \\
\text { to be abused" morphine/naltrexone, US } \\
\text { "good drug if you are concerned about drug abuse, it cannot get abused," hydromorphone, Canada } \\
\text { "safer than codeine and other opiates and non-addictive," tramadol, Canada }\end{array}$ \\
\hline Superiority & $5(8 \%)$ & $\begin{array}{l}\text { "infinitely better tolerated than tramadol." codeine/paracetamol, France } \\
\text { "better option than Tylenol } 3 \text { [codeine/paracetamol]" tramadol, Canada }\end{array}$ \\
\hline Multiple indications & $3(5 \%)$ & $\begin{array}{l}\text { "covers both acute phase and maintenance" tramadol, US } \\
\text { "medicine that is adapted to pain, many different levels," fentanyl, France } \\
\text { "use in a new indication." tramadol/paracetamol, Canada }\end{array}$ \\
\hline Reminder & $3(5 \%)$ & "reminder of the existence of the product." hydromorphone, Canada \\
\hline
\end{tabular}

${ }^{a}$ Each message could include more than one theme; reports are of the numbers of promotions for which key messages included each theme one or more times

${ }^{b}$ For 4 of the 69 promotions, doctors did not list any key messages

${ }^{c}$ As reported by the doctors 
Free samples were provided in $41 \%$ and food/drink in $18 \%$ of North American promotions. Both are banned in France. The doctors said they were somewhat or very likely to increase prescribing of the drug compared with before the sales visit for $45(65 \%)$ of promotions and judged quality of scientific information to be good or excellent for $41(59 \%)$.

This study has limitations. This was a small sample of opioid promotions and we did not audio record visits, instead we relied on doctors' memories in filling in a questionnaire after the visit.

\section{CONCLUSIONS}

In this series of opioid promotions by sales representatives at the height of opioid prescribing, benefits were emphasized and serious harms were rarely mentioned, with more frequent claims of safety and low abuse potential. Despite this information imbalance, the doctors generally judged the information positively and stated their willingness to prescribe. This overview provides a glimpse of the "nuts and bolts" of promotional messages that helped fuel the opioid epidemic.

Acknowledgements: We would like to thank Michael Wilkes, MarieDominique Beaulieu, and Genevieve Durrieu, leads in Sacramento, Montreal, and Toulouse of the larger the study on which this analysis is based, and Ellen Reynolds for study coordination. We also extend our thanks to all of the physicians who participated in the study.

Corresponding Author: Barbara Mintzes, PhD; Charles Perkins Centre and School of Pharmacy, Faculty of Medicine and Health, The University of Sydney, Camperdown, NSW 2006, Australia (e-mail: Barbara.mintzes@sydney.edu.au).

Funding This study was funded by the Institute of Health Services and Policy Research, Canadian Institutes of Health Research, and by the Michael Smith Health Research Foundation.

\section{Compliance with Ethical Standards:}

Conflict of Interest: In 2016-2019, Joel Lexchin was a paid consultant on two projects: one looking at developing principles for conservative diagnosis (Gordon and Betty Moore Foundation) and a second deciding what drugs should be provided free of charge by general practitioners (Government of Canada, Ontario Supporting Patient Oriented Research Support Unit and the St Michael's Hospital Foundation). He also received payment for being on a panel at the American Diabetes Association, for a talk at the Toronto Reference Library, for writing a brief in an action for side effects of a drug for Michael F. Smith, Lawyer, and from the Canadian Institutes of Health Research for presenting at a workshop on conflict of interest in clinical practice guidelines. He is currently a member of research groups that are receiving money from the Canadian Institutes of Health Research and the Australian National Health and Medical Research Council. He is member of the Foundation Board of Health Action International and the Board of Canadian Doctors for Medicare. He receives royalties from University of Toronto Press and James Lorimer \& Co. Ltd. for books he has written.

Barbara Mintzes is a member of Health Action International (HAI-Europe Association), a non-profit organization that supports public interests in pharmaceutical policy.

Disclaimer: The funders had no involvement in the design or conduct of the study; in the collection, management, analysis, or interpretation of the data; or in preparation, review, or approval of the manuscript or decision to submit for publication.

\section{REFERENCES}

1. Hadland SE, Cerda M, Li Y, Krieger MS, Marshall BDL. Association of Pharmaceutical Industry Marketing of Opioid Products to Physicians With Subsequent Opioid Prescribing. JAMA Intern Med. 2018;178(6):861-3.

2. Van Zee A. The promotion and marketing of oxycontin: commercial triumph, public health tragedy. Am J Public Health. 2009;99(2):221-7.

3. Hadland SE, Rivera-Aguirre A, Marshall BDL, Cerda M. Association of Pharmaceutical Industry Marketing of Opioid Products With Mortality From Opioid-Related Overdoses. JAMA Netw Open. 2019;2(1):e186007.

4. Chai G, Xu J, Osterhout J, Liberatore MA, Miller KL, Wolff C, et al. New Opioid Analgesic Approvals and Outpatient Utilization of Opioid Analgesics in the United States, 1997 through 2015. Anesthesiology. 2018; 128(5):953-66

5. Mintzes B, Lexchin $\mathbf{J}$, Sutherland JM, Beaulieu M-D, Wilkes MS, Durrieu G, et al. Pharmaceutical sales representatives and patient safety: a comparative prospective study of information quality in Canada, France and the United States. J Gen Intern Med. 2013;28(10): 1368-75.

Publisher's Note Springer Nature remains neutral with regard to jurisdictional claims in published maps and institutional affiliations. 